\title{
The Neuropeptide Y (NPY) Y1 Receptor Subtype Mediates NPY-induced Antidepressant-like Activity in the Mouse Forced Swimming Test
}

John P. Redrobe, Ph.D., Yvan Dumont, Ph.D., Alain Fournier, Ph.D., and Rémi Quirion, Ph.D.

The present study was undertaken to investigate the possible antidepressant-like effects of neuropeptide Y (NPY) in the mouse forced swimming test, an animal model widely used for the screening of potential antidepressant drugs. In addition, experiments were performed, using agonists and selective antagonists, to assess the potential role of NPY $Y_{1}$ and $Y_{2}$ receptor subtypes in this model. Complementary studies were performed in an open field apparatus to rule out any changes in locomotor activity that might have interfered with the interpretation of data from the mouse forced swimming test. Intracerebroventricular injections (0.03 nmole-3 nmole) of NPY, [Leu ${ }^{31}$ Pro $\left.^{34}\right] P Y Y\left(Y_{1}\right.$ agonist), $N P Y_{13-36}\left(Y_{2}\right.$ agonist), BIBP3226, BIBO3304 ( $Y_{1}$ antagonists) and BIIE0246 ( $Y_{2}$ antagonist) were performed 30 min prior to testing in the mouse forced swimming test and open field. NPY administration significantly reduced immobility time in a dose dependent manner $(p<.01$ vs. control group), as did [ $\left[\mathrm{Leu}^{31} \mathrm{Pro}^{34}\right] \mathrm{PYY}(p<.01$ vs. control group) and BIIE0246 ( $p<.05$ vs. control group). In contrast, BIBO3304, BIBP3226 and NPY ${ }_{13-36}$ did not display any activity at the doses tested. However, pretreatment with BIBO3304 or BIBP3226 significantly blocked the anti-immobility effects of NPY. Data from the open field demonstrated that BIIE0246 increased horizontal ambulation at the dose found to be active in the forced swimming test. Taken together, our results demonstrate that NPY displays antidepressant-like activity in the mouse forced swimming test, and suggest that this activity is mediated by the NPY $Y_{1}$ receptor subtype.

[Neuropsychopharmacology 26:615-624, 2002]

(C) 2002 American College of Neuropsychopharmacology.

Published by Elsevier Science Inc.
KEY WORDS: Neuropeptide $Y$; NPY $Y_{1}$ receptors; NPY $Y_{2}$ receptors; Antidepressant; Forced swimming test; Mouse

Neuropeptide Y (NPY) is a 36-amino acid peptide that is widely distributed in the central nervous system

From the Douglas Hospital Research Centre, Department of Psychiatry, McGill University, 6875 Blvd LaSalle, Verdun, Quebec, H4H 1R3, Canada (JPR, YD, AF, RQ), and INRS Santé, Université du Québec, Pointe-Claire, Quebec, H9R 1G6, Canada

Address correspondence to: Dr. Rémi Quirion, Douglas Hospital Research Centre, 6875 Blvd LaSalle, Verdun, QC, Canada H4H 1R3, Tel: (514) 762-3048, Fax: (514) 762-3034, E-mail: quirem@douglas.mcgill.ca

Received April 5, 2001; revised August 28, 2001; accepted November 6, 2001.

Online publication: $11 / 8 / 01$ at www.acnp.org/citations/ Npp110801200.
(CNS). Intracerebroventricular (ICV) administration of NPY stimulates food intake (Clark et al. 1985; Levine and Morley 1984; Stanley and Leibowitz 1984), modulates cognition (Flood et al. 1987; Redrobe et al. 1999), inhibits neuronal excitability (Colmers and Bleakman 1994) and has anticonvulsant effects (Vezzani et al. 1999). NPY modulates the secretion of various hypothalamic neuropeptides, stimulates the corticotrophic axis (Krysiak et al. 1999; Small et al. 1997) and has potent inhibitory effects on gonadotrophic and somatotrophic axes (Catzeflis et al. 1993). In addition, NPY is thought to play a role in the pathophysiology of certain mood disorders and in the mechanism of action of antidepressant drugs (Heilig et al. 1988; Caberlotto et al. 1998), 
however the receptor subtypes involved are not known. The numerous biological effects of NPY and related peptides are mediated by at least five molecularly defined classes of receptors known as $Y_{1}, Y_{2}, Y_{4}, Y_{5}$, and $Y_{6}$ subtypes (Michel et al. 1998).

Clinical studies have demonstrated decreased NPY levels in the cerebrospinal fluid (CSF) (Heilig and Widerlov 1990) and plasma (Nilsson et al. 1996) of depressed patients, when compared with healthy control subjects. In addition, NPY levels have been shown to be negatively correlated to scores of anxiety in clinically depressed patients (Heilig and Widerlov 1990), suggesting a possible link between low levels of NPY and predisposition to anxiety-related or stress-induced depression.

Moreover, pre-clinical studies have shown that electroconvulsive shock stimulation increased NPY gene expression (Heilig et al. 1988), as well as the expression of NPY mRNA in distinct brain regions in rats (Caberlotto et al. 1998; Mikkelsen et al. 1994). In addition, chronic antidepressant treatment has been shown to alter NPY and NPY $Y_{1}$-type receptor mRNA levels (Caberlotto et al. 1998), and to reduce NPY $Y_{2}$-type receptor densities in certain brain regions (Widdowson and Halaris 1991). Interestingly, NPY-like immunoreactivity and NPY $Y_{1}$-type receptor binding sites were shown to be decreased or increased, depending on the brain region studied, in the recently developed Flinders Sensitive Line (FSL) rats (Caberlotto et al. 1999), a purported genetic animal model of depression (Overstreet 1993; Overstreet et al. 1995).

Additional evidence of a role for NPY in depressive disorders is found in studies using the olfactory bulbectomized (OB) rat model of depression. Sub-chronic ICV administration of NPY attenuated the increase in ambulation, rearing, grooming and defecation scores consistently found when $\mathrm{OB}$ animals are tested in the open field (Song et al. 1996). Treatment with NPY also increased noradrenaline (NA) and serotonin (5-HT) levels in the amygdala and hypothalamus (Song et al. 1996). In addition, NPY reversed the supression of lymphocyte proliferation seen following OB (Song et al. 1994). A decrease in lymphocyte proliferation has also been reported in depressed patients (Kronfol and House 1989). Another study demonstrated that OB caused long term increases in the expression of the NPY gene in the olfactory/limbic system, suggesting that NPY plasticity may play some role in this model (Holmes et al. 1998).

More recently, it has been shown that NPY displayed antidepressant-like activity in the rat forced swimming test (Stogner and Holmes 2000). The sensitivity of the rat forced swimming test, when compared with the mouse forced swimming test, was unclear as several groups had difficulty obtaining reliable antidepressantlike effects with the selective serotonin re-uptake inhibi- tors (SSRIs) when using rats (for review see Borsini and Meli 1988). Recently, the procedure of the rat forced swimming test was modified in order to score swimming and climbing behaviors, in addition to immobility time (Detke et al. 1995). This modification in scoring allowed the authors to suggest that NA-ergic and 5-HTergic antidepressants produced different patterns of active behavior in the rat version of this model. The mouse version of the test also displays a high degree of pharmacological validity as evidenced by its sensitivity to major classes of antidepressant treatments, tricyclic compounds, monoamine oxidase inhibitors, atypical antidepressants, SSRIs and electroconvulsive shock (Borsini and Meli 1988). The diversity of results between the two test situations (rat vs. mouse) may be an important indication that the effects of certain antidepressant drugs are mediated by different substrates, and that their behavioral effects are expressed under different genetic and laboratory conditions.

It was therefore of significant interest to investigate the possible antidepressant-like activity of NPY in the mouse forced swimming test, using the established antidepressant imipramine as a positive control. In addition, the NPY receptor subtypes involved were assessed by investigating the possible antidepressant-like profile of agonists and selective antagonists of NPY $Y_{1}$ and $Y_{2}$ receptors. Complementary studies were conducted in the open field to rule out any false-positive results arising from drug-induced changes in locomotor performance.

\section{MATERIALS AND METHODS}

\section{Animals}

Naive male CD-one mice (Charles River, St-Constant, Quebec, Canada), weighing 20-24 g were used throughout this study. They were singly housed under standard laboratory conditions ( $12 \mathrm{~h}$ light $/ 12 \mathrm{~h}$ dark cycle, lights on at 7:00 A.M., food and water ad libitum). Each experimental group consisted of ten randomly chosen mice and animals were only used once. Animal care was provided according to protocols and guidelines approved by McGill University and the Canadian Council of Animal Care.

\section{Surgery}

Animals were carefully weighed and received an intraperitoneal injection (IP) of a ketamine $\mathrm{HCl}$ (Vetrepharm, London, $\mathrm{ON}$ ): xylazine $\mathrm{HCl}$ (Novopharm, Toronto, $\mathrm{ON}$ ): acepromazine maleate (Ayerst, Montréal, QC) mixture (1: 0.5 : 0.1 ratio; $0.03 \mathrm{ml} .20 \mathrm{~g}^{-1}$ body weight). The respiratory rate was monitored throughout the entire surgical procedure. Animals were then implanted with permanent 26 gauge steel guide cannula (Plastics One, Roanoke, VA) unilaterally above the 
left lateral ventricle. Coordinates were taken from the atlas of Franklin and Paxinos (1996): anterior-posterior, $-0.6 \mathrm{~mm}$ with respect to bregma; lateral, $+1.1 \mathrm{~mm}$; ventral, $-1 \mathrm{~mm}$ with respect to the surface of the skull. Cannulae were secured with dental cement surrounding two jeweller's screws affixed to the skull. The animals were then placed under a warming lamp until they had sufficiently recovered from the anesthetic, before being individually housed for a period of seven days post-surgery.

\section{Drugs and Treatment}

NPY, [Leu ${ }^{31}$ Pro $\left.^{34}\right]$ PYY and NPY ${ }_{13-36}$ were synthesized in our laboratory as previously described (Forest et al. 1990), while BIBP3226 ((R)-N-[[4-hydroxyphenyl]methyl]- $N^{2}$-(diphenylacetyl)-argininamide; Rudolf et al. 1994), BIIE0246 ((S)-N2-[[1-[2-[4-[(R,S)-5,11-Dihydro-6(6h)-oxodibenz[b,e] azepin-11-yl]-1-piperazinyl]-2-oxoethyl]cyclopentyl]acetyl]$\mathrm{N}$-[2-[1,2-dihydro-3,5 (4H)-dioxo-1,2-diphenyl-3H-1,2,4triazol-4-yl]ethyl]-argininamid; Doods et al. 1999; Dumont et al. 2000a) and BIBO3304 ((R)-N-[[4-(aminocarbonylaminomethyl)-phenyl]methyl]-N(2)-(diphenylacetyl)-arginamide trifluoroacetate; Wieland et al. 1998) were generously provided by Boeringer Ingelheim (Germany).

The mice were randomly divided into groups and treated with: NPY $(0.01,0.03,0.1,0.3,1$ or 3 nmole); the NPY $Y_{1}$-type receptor agonist, [Leu $\left.{ }^{31} \mathrm{Pro}^{34}\right] \mathrm{PYY}$; the selective NPY $Y_{1}$-type receptor antagonists, BIBP3226 and BIBO3304; the NPY $Y_{2}$-type receptor agonist, $\mathrm{NPY}_{13-36}$; the selective NPY $Y_{2}$-type receptor antagonist, BIIE0246 ( 0.003 to 3 nmole) or $0.9 \%$ isotonic saline ICV via an injection cannula extending $1 \mathrm{~mm}$ beyond guide cannula tip (total injection volume: $2 \mu \mathrm{l}$; flow-rate: $1 \mu \mathrm{l} / \mathrm{min}$ ). Imipramine $\mathrm{HCl}$ (RBI, Natick, MA; 8 and $32 \mathrm{mg} \cdot \mathrm{kg}^{-1}$; doses which do not increase locomotor activity, (Redrobe et al. 1996)) was administered IP as a positive control. Animals were tested in the mouse forced swimming test or open field $30 \mathrm{~min}$ following injection. For studies investigating the effects of BIBP3226, BIBO3304 or BIIE0246 on NPY-induced antidepressant-like activity, pretreatment was performed 45 min before testing in the mouse forced swimming test.

All molecules were dissolved in $0.9 \%$ isotonic saline, except BIBP3226 and BIIE0246 which were dissolved in a $1 \% \mathrm{DMSO} /$ saline solution. Control animals for these groups received the same $1 \% \mathrm{DMSO} /$ saline solution.

\section{Measurement of Immobility Time}

The forced swimming test employed was essentially similar to that described elsewhere (Porsolt et al. 1977). Briefly, mice were dropped individually into glass cylinders (height: $25 \mathrm{~cm}$, diameter: $10 \mathrm{~cm}$ ) containing 10 $\mathrm{cm}$ of water, maintained at $23-25^{\circ} \mathrm{C}$, and left there for 6 min. A mouse was judged to be immobile when it floated in an upright position, and made only small movements to keep its head above water. The duration of immobility was recorded during the last $4 \mathrm{~min}$ of the 6-min testing period.

\section{Measurement of Locomotor Activity}

Thirty minutes following ICV injections, as described earlier, mice were tested in the open field (Gray and Lalljee 1974). Each animal was placed into the center of the apparatus, which consisted of a square base $(70 \times 70$ $\mathrm{cm}$ ) surrounded by a $75 \mathrm{~cm}$ high wall. Illumination was provided by a $60 \mathrm{~W}$ bulb, positioned $90 \mathrm{~cm}$ above the floor of the apparatus. Horizontal ambulation and the number of central crossings were measured, over a 10 min period, by a video tracking system connected to a computer equipped with the commercially available HVS image system (HVS, UK) for the analysis of open field activity.

\section{Verification of Cannula Placement}

Cannula placement and function were verified within one week of testing. Mice were injected ICV with $2 \mu l$ of methyl blue dye $(2 \mathrm{mg} / \mathrm{ml})$, and decapitated. Brains were rapidly removed and dissected to ensure the dye had reached the ventricles. No subjects were excluded from the data analysis because of improper cannula placement.

\section{Statistical Analysis}

Data were analyzed using a one-way analysis of variance, followed by post-hoc Bonferroni tests to assess individual group differences. Data were considered statistically significant when $p<.05$.

\section{RESULTS}

\section{Effect of NPY in the Mouse Forced Swimming Test and Open Field}

As shown in Figure 1, Panel A, ICV injection of NPY significantly increased mobility time ( 0.1 to 3 nmole; $p<.01$ vs. vehicle-control group) in the mouse forced swimming test. Administration of 0.01 or 0.03 nmole NPY failed to induce antidepressant-like effects. As shown in Figure 1, Panel B, NPY decreased horizontal ambulation in the open field, effects that were statistically significant at a dose of 0.3 nmole ( $p<.05$ vs. vehicle-control group). Figure 1, Panel C, demonstrates the antidepressant-like activity of imipramine at a dose of $32 \mathrm{mg} . \mathrm{kg}^{-1}$ ( $p<.01 \mathrm{vs.} \mathrm{vehicle-control} \mathrm{group),} \mathrm{whereas}$ a dose of $8 \mathrm{mg} \cdot \mathrm{kg}^{-1}$ failed to induce anti-immobility effects. 
A

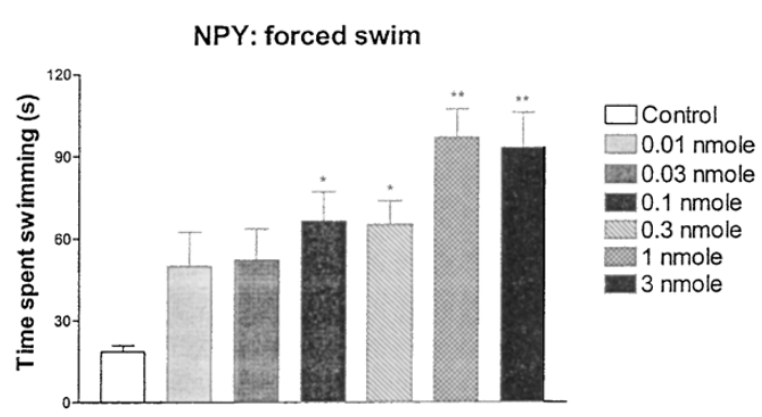

B

NPY: open field ambulation

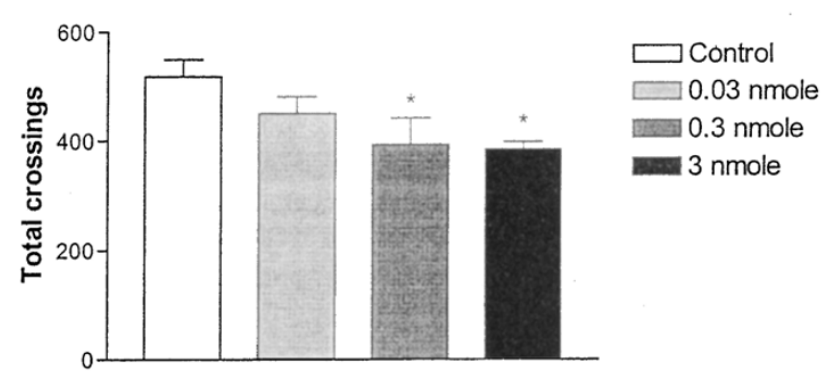

C

Imipramine: forced swim

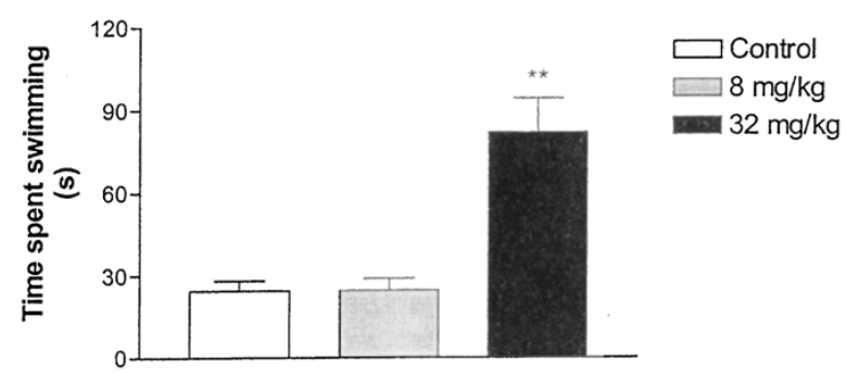

Figure 1. Effect of NPY (0.01-3 nmole, ICV) in (A) the mouse forced swimming test, and (B) open field. (C) Effect of imipramine ( 8 and $32 \mathrm{mg}^{\mathrm{kg}}{ }^{-1}, \mathrm{IP}$ ) in the mouse forced swimming test. Results expressed as means \pm S.E.M. $(n=10) .{ }^{*} p<$ $.05,{ }^{* *} p<.01$ vs. vehicle-control group.

\section{Effect of [ $\left.\mathrm{Leu}^{31} \mathrm{Pro}^{34}\right] \mathrm{PYY}$ in the Mouse Forced Swimming Test and Open Field}

ICV injection of the NPY $Y_{1}$-type receptor agonist, $\left[\mathrm{Leu}^{31} \mathrm{Pro}^{34}\right] \mathrm{PYY}$, significantly reduced immobility time at a dose of 3 nmole (Figure 2, Panel A; $p<.01$ vs. vehicle-control group). Administration with 0.03 nmole $\left[\mathrm{Leu}^{31} \mathrm{Pro}^{34}\right]$ PYY failed to induce significant antidepressant-like effects (Figure 2, Panel A). As shown in Figure 2, Panel B, [Leu ${ }^{31}$ Pro $\left.^{34}\right]$ PYY significantly reduced hori- zontal ambulation in the open field at a dose of 3 nmole ( $p<.05$ vs. vehicle-control group), whereas the number of central crossings was not affected (Figure 2, Panel C).

\section{Effect of BIBP3226 in the Mouse Forced Swimming Test and Open Field}

ICV administration of the selective NPY $Y_{1}$-type receptor antagonist, BIBP3226 (0.03 or 3 nmole), failed to induce significant changes in the mouse forced swimming test (Figure 3, Panel A) or ambulation in the open

A

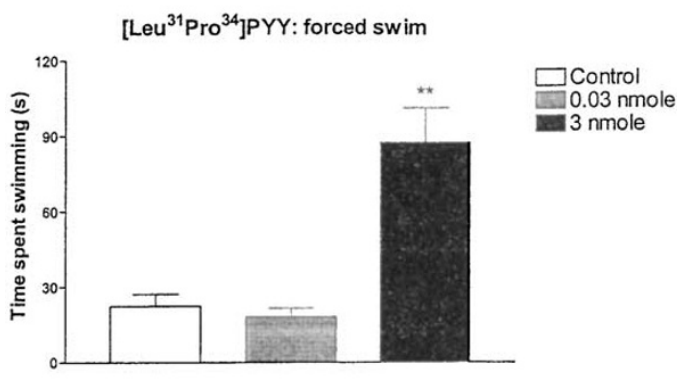

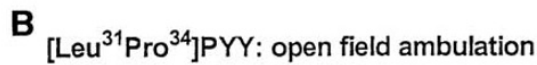
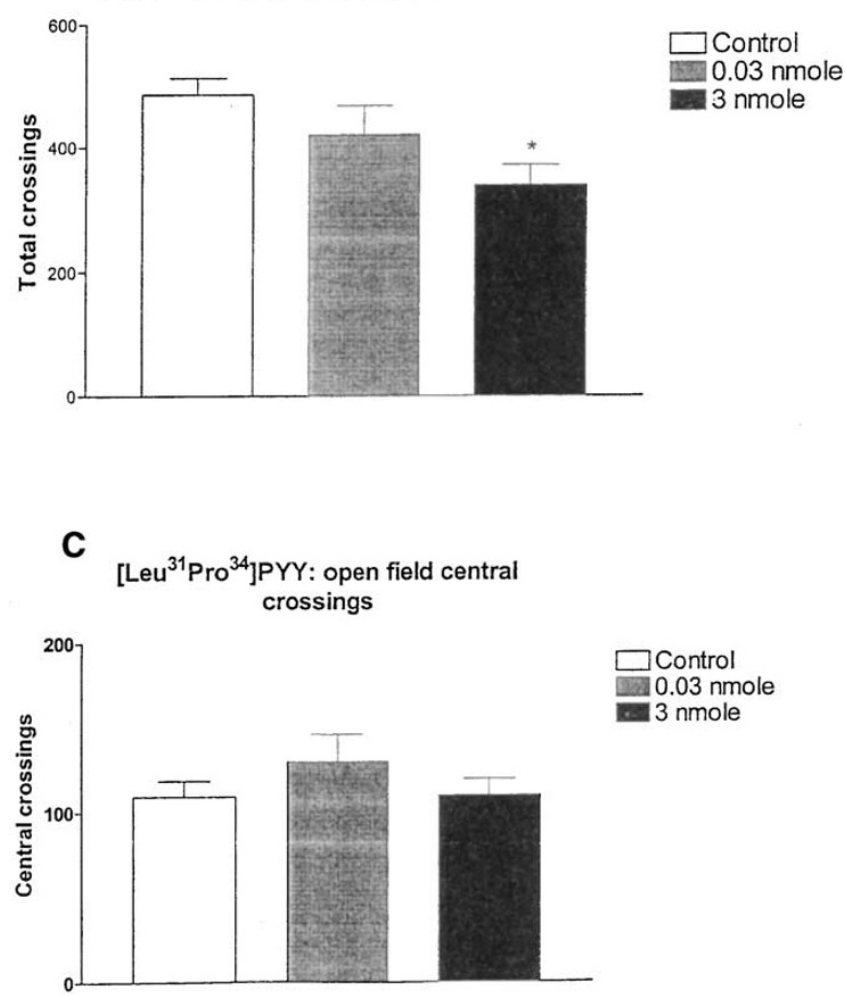

Figure 2. Effect of [Leu $\left.{ }^{31} \mathrm{Pro}^{34}\right] \mathrm{PYY}(0.03$ and 3 nmole, ICV) in (A) the mouse forced swimming test, and $(B, C)$ open field. Results expressed as means \pm S.E.M. $(n=10) .{ }^{*} p<$ $.05,{ }^{* *} p<.01$ vs. vehicle-control group. 
A

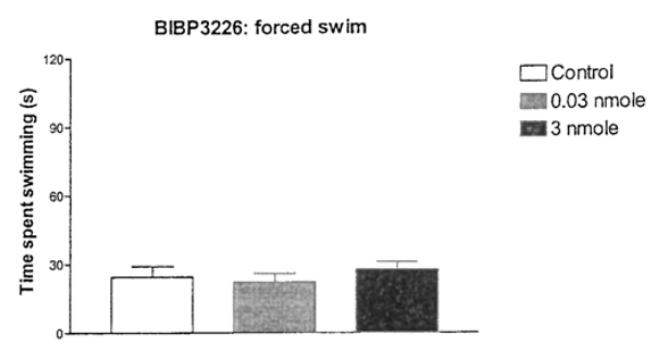

B BIBP3226: open field ambulation

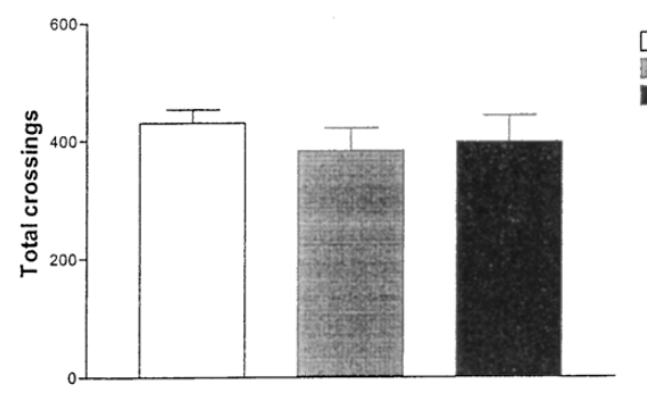

C BIBP3226: open field central crossings

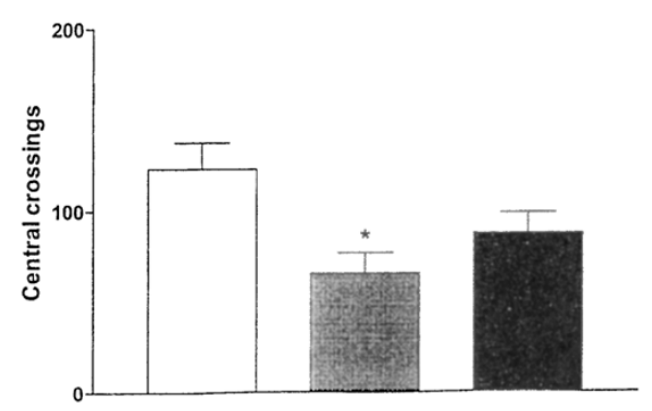

Figure 3. Effect of BIBP3226 (0.03 and 3 nmole, ICV) in (A) the mouse forced swimming test, and $(B, C)$ open field. Results expressed as means \pm S.E.M. $(n=10) .{ }^{*} p<.05$ vs. vehicle-control group.

field (Figure 3, Panel B). However, treatment with this molecule reduced the number of crossings in the central area of the open field apparatus (Figure 3, Panel C).

\section{Effect of BIBO3304 in the Mouse Forced Swimming Test and Open Field}

Treatment with BIBO3304 did not result in any significant changes in the mouse forced swimming test (Figure 4, Panel A) or open field measurements (Figure 4, Panel B and Figure 4, Panel C).

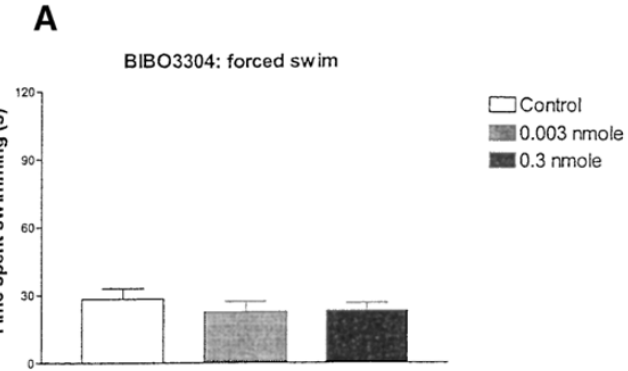

B

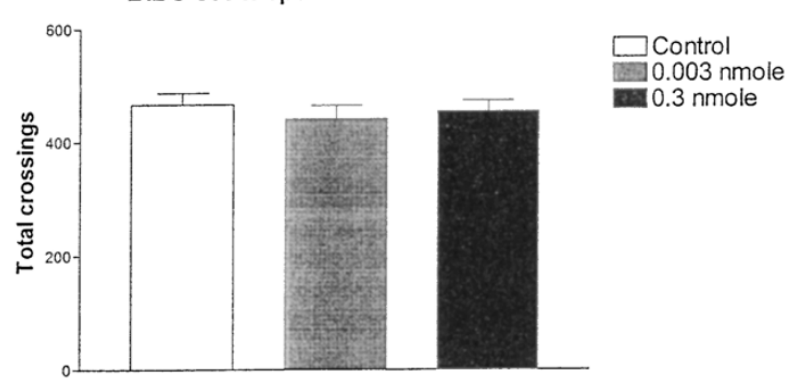

C

BIBO 3304: open field central crossings

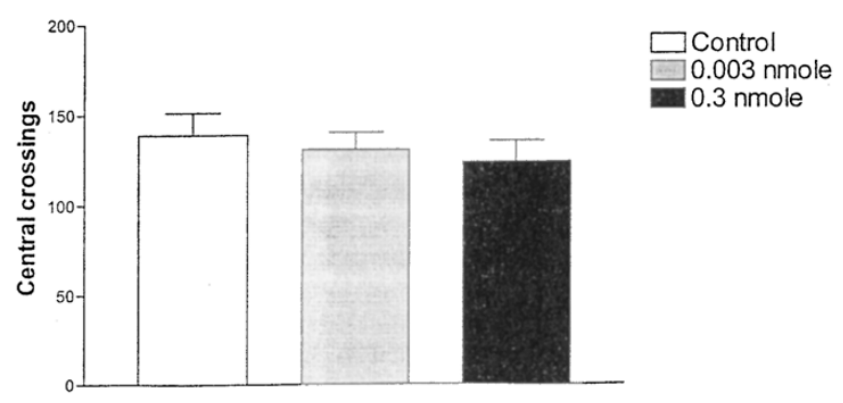

Figure 4. Effect of BIB03304 (0.03 and 3 nmole, ICV) in (A) the mouse forced swimming test, and $(B, C)$ open field. Results expressed as means \pm S.E.M. $(n=10)$.

\section{Effect of NPY N3-36 in the Mouse Forced Swimming Test and Open Field}

Treatment with the NPY $\mathrm{Y}_{2}$-type receptor agonist, $\mathrm{NPY}_{13-36}(0.03$ or 3 nmole) did not induce any antidepressant-like effects in the mouse forced swimming test (Figure 5, Panel A). Similarly, Figure 5, Panel B, and Figure 5, Panel $\mathrm{C}$, show that ICV administration of $\mathrm{NPY}_{13-36}$ did not induce any significant changes in horizontal ambulation or central crossings in the open field at the doses tested. 
A
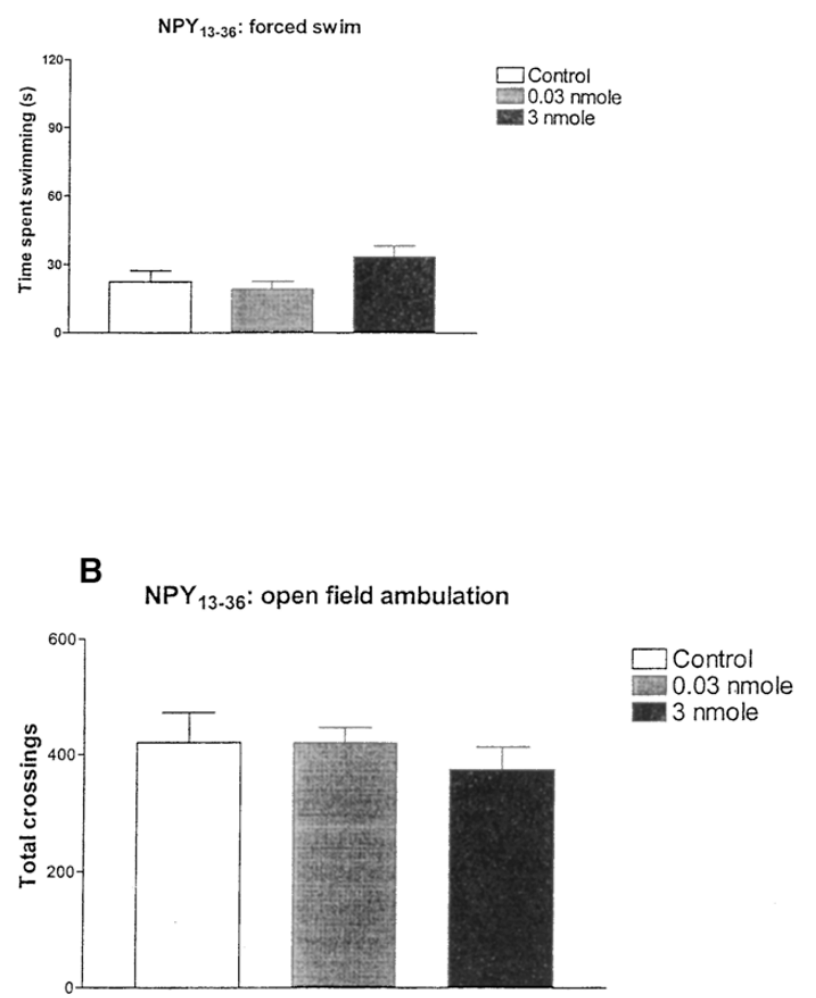

C

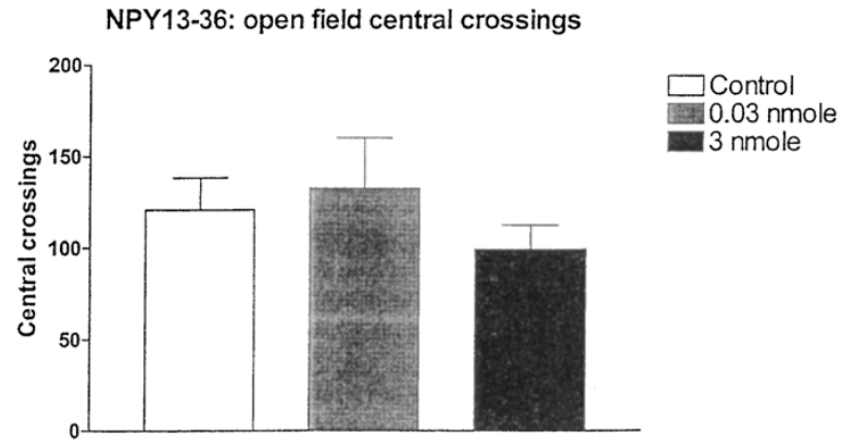

Figure 5. Effect of $\mathrm{NPY}_{13-36}(0.03$ and 3 nmole, ICV) in (A) the mouse forced swimming test, and $(B, C)$ open field. Results expressed as means \pm S.E.M. $(n=10)$.

\section{Effect of BIIE0246 in the Mouse Forced Swimming Test and Open Field}

As shown in Figure 6, Panel A, ICV injection of the selective NPY $\mathrm{Y}_{2}$-type receptor antagonist, BIIE0246 (3 nmole) significantly increased mobility time in the mouse forced swimming test ( $p<.05$ vs. vehicle-control group). However, ICV administration with BIIE0246 was also found to increase horizontal ambulation in the open field at this dose (Figure 6, Panel B; $p<.05$ vs. vehicle-control group), whereas central crossings were unaffected (Figure 6, Panel C).
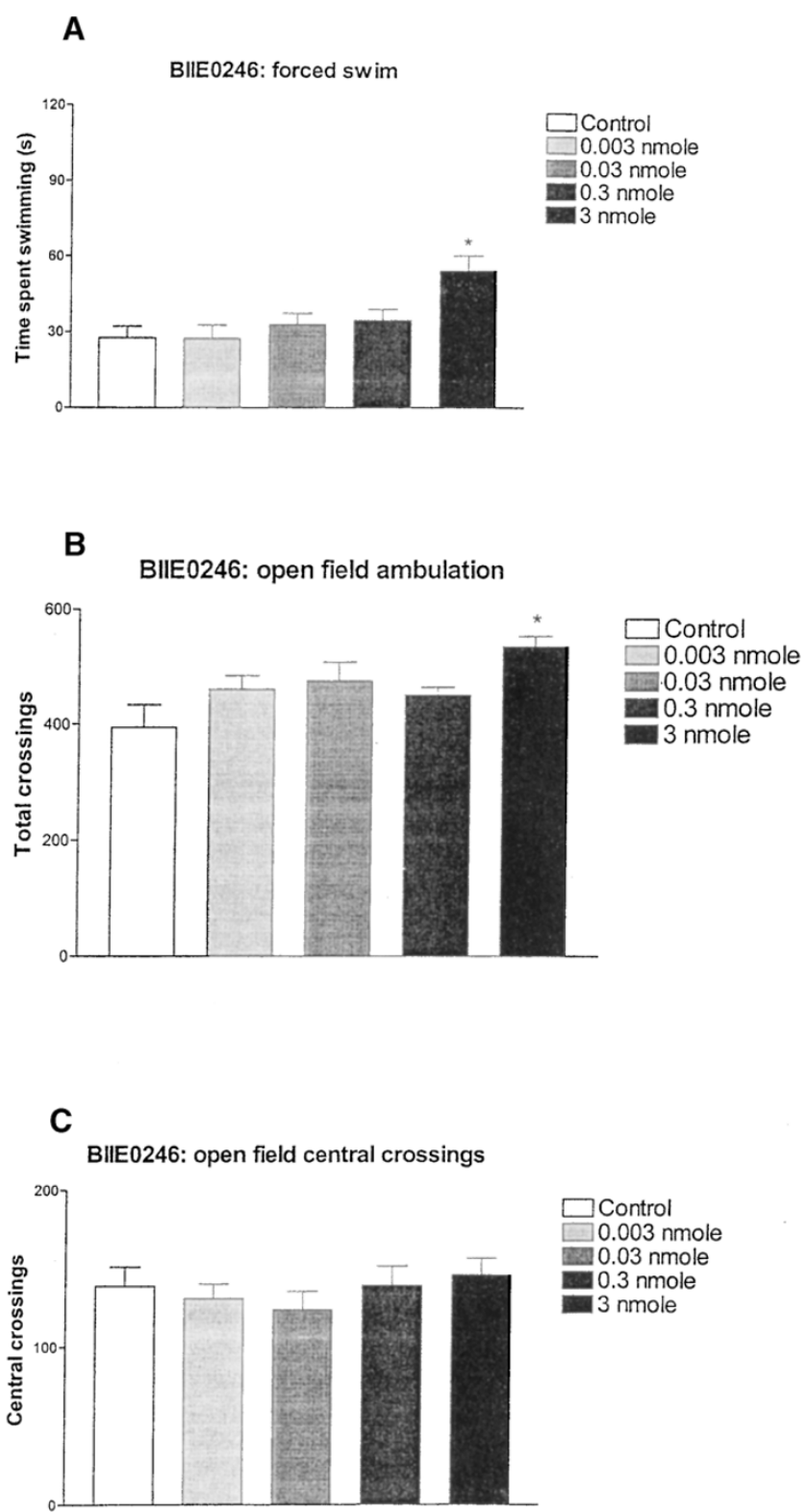

Figure 6. Effect of BIIE0246 (0.003 to 3 nmole, ICV) in (A) the mouse forced swimming test, and $(B, C)$ open field. Results expressed as means \pm S.E.M. $(n=10) .{ }^{*} p<.05$ vs. vehicle-control group.

\section{Effects of pretreatment with BIBP3226, BIBO3304 or BIIE0246 on the Antidepressant-like Effects of NPY in the Mouse Forced Swimming Test}

Pretreatment with BIBP3226 (3 nmole, a dose that did not modify horizontal ambulation in the open field) significantly blocked ( $p<.01$ vs. NPY-treated group) the antidepressant-like effects of NPY ( 3 nmole) in the mouse forced swimming test (Figure 7, Panel A), as did BIBO3304 (Figure 7, Panel B). In contrast, pretreatment with BIIE0246 did not modify the anti-immobility effects of NPY (Figure 7, Panel C). 

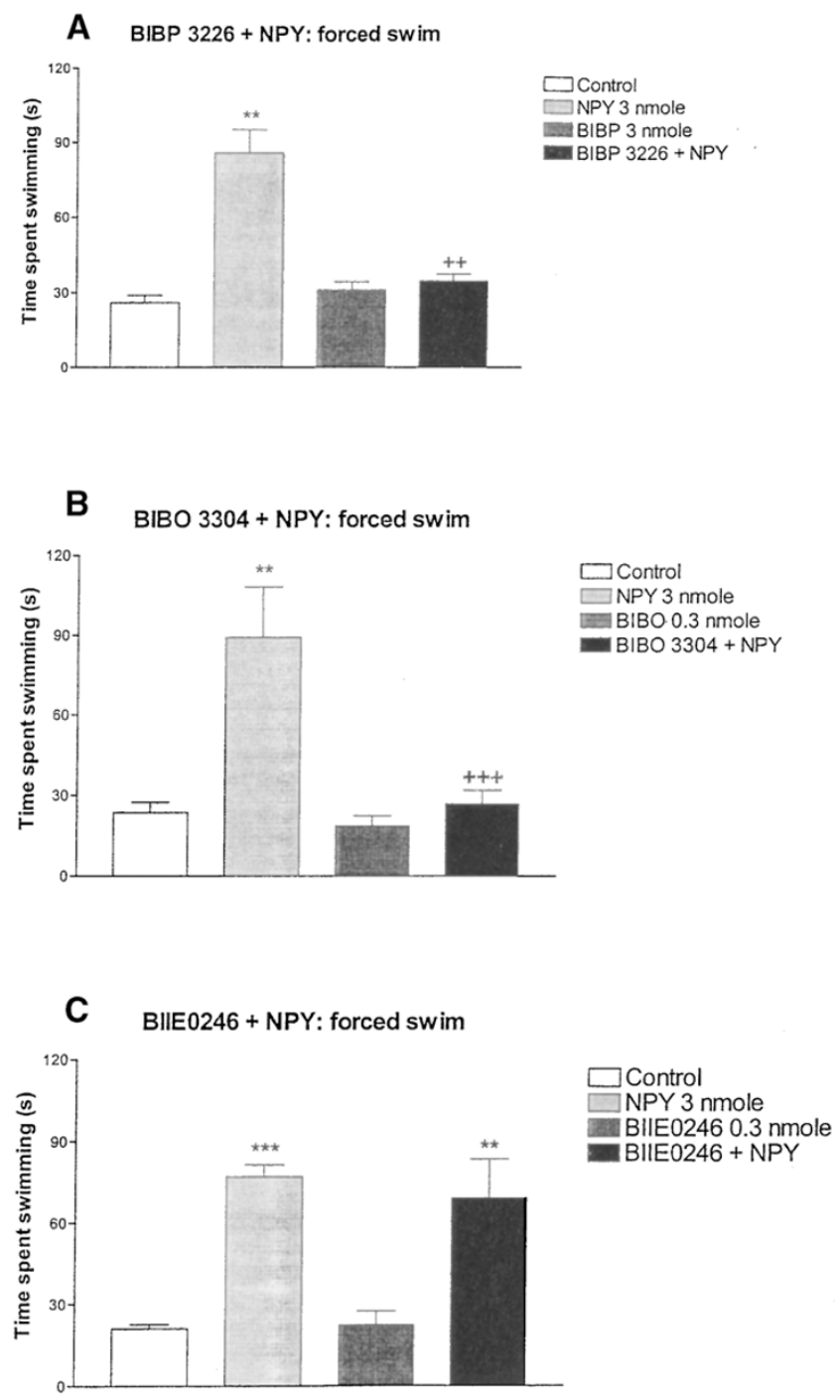

Figure 7. Effects of pretreatment with (A) BIBP3226 (3 nmole, ICV), (B) BIBO3304 (0.3 nmole, ICV), or (C) BIIE0246 (0.3 nmole, ICV) on the antidepressant-like effects of NPY (3 nmole, ICV) in the mouse forced swimming test. Results expressed as means \pm S.E.M. $(n=10){ }^{* *} p<.01,{ }^{* * *} p<.001$ vs. vehicle-control group. $++p<.01,+++p<.001$ vs. NPY-treated group.

\section{DISCUSSION}

The present study demonstrates that NPY exerted dosedependent antidepressant-like activity in the mouse forced swimming test following ICV administration. The magnitude of this effect was similar to that observed following treatment with imipramine, an antidepressant drug acting primarily via blockade of $5-\mathrm{HT}$ and NA re-uptake.

It has been suggested that NPY may induce antidepressant activity via the modulation of 5-HT/NA neurotransmission (Song et al. 1996). Anatomical evidence lends some support to this hypothesis as NPY is co-local- ized with 5-HT and NA-ergic neurons (Blessing et al. 1986; Everitt et al. 1984) and modulates the release of 5-HT and NA, two neurotransmitter systems targeted by many antidepressant drugs (Finta et al. 1992; Martire et al. 1993; Schlicker et al. 1991). Indeed, it was shown that administration of NPY or NPY $\mathrm{Y}_{1}$ receptor agonists increased brain levels of both 5-HT and NA (Song et al. 1996; Hastings et al. 1997). Moreover, behavioral data have shown that NPY exerted an antidepressant-like profile, in a modified version of the rat forced swim test (Stogner and Holmes 2000). Using this method, it was concluded that NPY-treated animals presented escapelike behavior preferentially similar to that observed following SSRI administration (Stogner and Holmes 2000). Indeed, several studies have demonstrated that SSRI administration modified NPY gene expression, NPY mRNA and NPY receptor densities in the rodent CNS (Caberlotto et al. 1998, 1999). However, the possible involvement of other neurotransmitter systems, e.g., GABA or dopamine, that may serve to mediate the antidepressant-like effects of NPY, cannot be ruled out at this time.

Our experiments also demonstrated that the NPY $\mathrm{Y}_{1}$ receptor agonist, [Leu ${ }^{31}$ Pro $\left.^{34}\right] \mathrm{PYY}$, significantly reduced immobility time in the mouse forced swimming test, and thus implicate this receptor subtype in the antidepressant-like effects of NPY in this model. In addition, the magnitude of this effect was similar to that observed with the highest dose of NPY (Figure 1, Panel A), suggesting that the involvement of other NPY receptor subtypes, other than $\mathrm{Y}_{1}$, is unlikely. However, as $\left[\mathrm{Leu}^{31} \mathrm{Pro}^{34}\right.$ PYY also has some agonist activity at $\mathrm{Y}_{5}$ receptors (Michel et al. 1998), the involvement of this receptor subtype cannot be completely excluded. Studies performed in the open field revealed that ICV $\left[\mathrm{Leu}^{31} \mathrm{Pro}^{34}\right] \mathrm{PYY}$ administration reduced horizontal ambulation, without influencing central crossings, and thus rules out any non-specific effects in the mouse forced swimming test. Further evidence of a role for the NPY $Y_{1}$ receptor subtype is drawn from the observation that pretreatment with the NPY $Y_{1}$-type receptor antagonists, BIBP3226 and BIBO3304, significantly attenuated the antidepressant-like effects of NPY in the forced swim. We observed that ICV administration with these molecules was devoid of activity in the mouse forced swimming test per se, but BIBP3226 did show a tendency to reduce the number of central crossings in the open field. As mentioned earlier, it could be postulated that the effects seen in the mouse forced swim following $\left[\mathrm{Leu}^{31} \mathrm{Pro}^{34}\right] \mathrm{PYY}$ (an NPY $\mathrm{Y}_{1}$ receptor agonist (Dumont et al. 1998; Michel et al. 1998)) administration may have been mediated by both NPY $\mathrm{Y}_{1}$ and $\mathrm{Y}_{5}$ receptors. However, this seems unlikely as BIBP3226 (an NPY $Y_{1}$ receptor antagonist with very low affinity for NPY $\mathrm{Y}_{5}$ receptors (Rudolf et al. 1994; Doods et al. 1996)) and BIBO3304 (an antagonist showing ten times more potency for the $\mathrm{Y}_{1}$ receptor than BIBP3226 (Wieland et al. 
1998)) completely blocked the antidepressant-like effects of NPY in the forced swim test. This matter will only be resolved with the advent of selective NPY $Y_{5}$ receptor antagonists, which are not yet widely available. Hence, the results of the present study suggest that the development of synthetic NPY $Y_{1}$ agonists may serve as a new family of pharmacotherapeutic agents for the treatment of depressive disorders. Further studies are warranted to elucidate the possible role played by other NPY receptor subtypes, e.g., the NPY $Y_{4}, Y_{5}$ and $Y_{6}$ receptors. However such studies are, thus far, problematic as selective and potent agonists and antagonists for these receptor subtypes are not widely available (Michel et al. 1998; Dumont et al. 2000b).

The open field is often used as a model for the investigation of potential anxiolytic-like activity, in addition, this test is also widely used to measure gross changes in locomotor activity. It has been shown that ICV administration of NPY induces dose-dependent suppression of open field activity (Heilig and Murison 1987), results which concur with those of the present study. In contrast, other authors have reported moderate increases in exploratory activity with relatively low doses (Smialowski et al. 1992). NPY-induced suppression of activity is also observed when similar doses are administered prior to testing in spontaneous locomotor activity and home cage activity monitors (Heilig et al. 1988; Heilig and Murison 1987). The use of the open field in the present study stems from the need to ensure that increases in mobility time in the forced swimming test were not due to increases in gross locomotor performance.

The selective NPY $\mathrm{Y}_{2}$-type receptor antagonist, BIIE0246, marginally but significantly reduced immobility time in the mouse forced swimming test (Figure 6, Panel A); however, treatment with this molecule also increased horizontal ambulation in the open field at the dose found to be active in the forced swim test. This rather surprising result could imply that BIIE0246 may have induced some indirect non-specific effects, at the higher dose, and therefore increased general activity in the open field. A possible explanation for this effect could be drawn from an NPY $\mathrm{Y}_{2}$-mediated activation of the dopaminergic system. It has been demonstrated that NPY modulates the release of dopamine via an NPY $Y_{2}$ receptor controlled mechanism (Ault and Werling 1997). In addition, dopamimetics have been shown to display antidepressant-like activity in the forced swimming test (Willner 1997), as well as increased activity in the open field (Dahl and Gotestam 1989). As there is little or no behavioral data published to date using BIIE0246, a full and more detailed psychopharmacological profile of this molecule is warranted before any firm conclusions can be made.

A possible role for the NPY $Y_{2}$ receptor subtype in the activity of NPY in this model however seems un- likely, as pretreatment with BIIE0246 (0.3 nmole) failed to antagonize NPY-induced ( 3 nmole) antidepressantlike effects. This hypothesis is further supported by the fact that the NPY $Y_{2}$ receptor agonist, NPY ${ }_{13-36}$, failed to induce significant anti-immobility activity in the mouse forced swimming test. Indeed, it has been shown that agonists of this receptor subtype reduced basal and stimulated NPY release, both in vitro (Chen et al. 1997) and in vivo (King et al. 1999), and thus may explain the lack of activity of NPY ${ }_{13-36}$ in the mouse forced swimming test.

In conclusion, the present study supports the hypothesis that NPY exerts antidepressant like effects and suggest that this activity is mediated by the NPY $Y_{1}$ receptor subtype, as assessed in an acute animal model of depression.

\section{ACKNOWLEDGMENTS}

This study was supported by a grant from the Canadian Institute of Health Research (CIHR) to R.Q. A.F. is a recipient of a "Chercheur-Boursier" grant from the "Fonds de la Recherche en Santé du Quebec (FRSQ)."

\section{REFERENCES}

Ault DT, Werling LL (1997): Differential modulation of NMDA-stimulated [3H]dopamine release from rat striatum by neuropeptide $\mathrm{Y}$ and sigma receptor ligands. Brain Res 760:210-217

Blessing WW, Howe PR, Joh TH, Oliver JR, Willoughby JO (1986): Distribution of tyrosine hydroxylase and neuropeptide Y-like immunoreactive neurons in rabbit medulla oblongata, with attention to colocalization studies, presumptive adrenaline-synthesizing perikarya, and vagal preganglionic cells. J Comp Neurol 248:285-300

Borsini F, Meli A (1988): Is the forced swimming test a suitable model for revealing antidepressant activity? Psychopharmacology 94:147-160

Caberlotto L, Fuxe K, Overstreet DH, Gerrard P, Hurd YL (1998): Alterations in neuropeptide $\mathrm{Y}$ and $\mathrm{Y} 1$ receptor mRNA expression in brains from an animal model of depression: region specific adaptation after fluoxetine treatment. Mol Brain Res 59:58-65

Caberlotto L, Jimenez P, Overstreet DH, Hurd YL, Mathe AA, Fuxe K (1999): Alterations in neuropeptide $Y$ levels and $\mathrm{Y} 1$ binding sites in the Flinders Sensitive rats, a genetic animal model of depression. Neurosci Lett 265: 191-194

Catzeflis C, Pierroz DD, Rohner-Jeanrenaud F, Rivier JE, Sizonenko PC, Aubert ML (1993): Neuropeptide Y administered chronically into the lateral ventricle profoundly inhibits both the gonadotropic and the somatotropic axis in intact adult female rats. Endocrinology 132:224-234

Chen X, DiMaggio DA, Han SP, Westfall TC (1997): Autoreceptor-induced inhibition of neuropeptide $\mathrm{Y}$ release 
from PC-12 cells is mediated by Y2 receptors. Am J Physiol 273:H1737-H1744

Clark JT, Kalra PS, Kalra SP (1985): Neuropeptide Y stimulates feeding but inhibits sexual behavior in rats. Endocrinology 117:2435-2442

Colmers WF, Bleakman D (1994): Effects of neuropeptide Y on the electrical properties of neurons. Trends Neurosci 17:373-379

Dahl CB, Gotestam KG (1989): An open field study of antidepressant drugs. Pharmacol Toxicol 64:302-307

Detke MJ, Rickels M, Lucki I (1995): Active behaviors in the rat forced swimming test differentially produced by serotonergic and noradrenergic antidepressants. Psychopharmacology 121:66-72

Doods HN, Gaida W, Wieland HA, Doliinger H, Schnorrenberg G, Esser F, Engel W, Eberlein W, Rudolf K (1999): BIIE0246: a selective and high affinity neuropeptide $Y$ Y(2) receptor antagonist. Eur J Pharmacol 384:R3-R5

Doods HN, Wieland HA, Engel W, Eberlein W, Willim KD, Entzeroth M, Wienen W, Rudolf K (1996): BIBP 3226, the first selective neuropeptide $\mathrm{Y} 1$ receptor antagonist: a review of its pharmacological properties. Regul Pept 65:71-77

Dumont Y, Cadieux A, Doods H, Pheng LH, Abounader R, Hamel E, Jacques D, Regoli D, Quirion R (2000a): BIIE0246, a potent and highly selective non-peptide neuropeptide Y Y(2) receptor antagonist. Br J Pharmacol 129:1075-1088

Dumont Y, Fournier A, Quirion R (1998): Expression and characterization of the neuropeptide Y Y5 receptor subtype in the rat brain. J Neurosci 18:5565-5574

Dumont Y, Jacques D, St-Pierre JA, Tong Y, Parker R, Herzog H, Quirion R (2000b): Neuropeptide Y, peptide YY and pancreatic polypeptide receptor proteins and mRNAs in mammalian brains. In Quirion R, Björklund A, Hökfelt T (eds), Handbook of Chemical Neuroanatomy, Vol. 16. London, Elsevier Science, pp 375-475.

Everitt BJ, Hokfelt T, Terenius L, Tatemoto K, Mutt V, Goldstein M (1984): Differential co-existence of neuropeptide Y (NPY)-like immunoreactivity with catecholamines in the central nervous system of the rat. Neuroscience 11:443-462

Finta EP, Regenold JT, Illes P (1992): Depression by neuropeptide $\mathrm{Y}$ of noradrenergic inhibitory postsynaptic potentials of locus coeruleus neurones. Naunyn Schmiedebergs Arch Pharmacol 346:472-474

Flood JF, Hernandez EN, Morley JE (1987): Modulation of memory processing by neuropeptide Y. Brain Res 421:280-290

Forest M, Martel JC, St-Pierre S, Quirion R, Fournier A (1990): Structural study of the N-terminal segment of neuropeptide tyrosine. J Med Chem 33:1615-1619

Franklin KBJ, Paxinos G (1996): The mouse brain. London, Academic Press

Gray JA, Lalljee B (1974): Sex differences in emotional behaviour in the rat: correlation between open-field defecation and active avoidance. Anim Behav 22:856861

Hastings JA, Pavia JM, Morris MJ (1997): Neuropeptide Y and [Leu31,Pro34]neuropeptide $\mathrm{Y}$ potentiate potas- sium-induced noradrenaline release in the paraventricular nucleus of the aged rat. Brain Res 750:301-304

Heilig M, Murison R (1987): Intracerebroventricular neuropeptide $Y$ suppresses open field and home cage activity in the rat. Regul Pept 19:221-231

Heilig M, Wahlestedt C, Ekman R, Widerlov E (1988): Antidepressant drugs increase the concentration of neuropeptide $\mathrm{Y}$ (NPY)-like immunoreactivity in the rat brain. Eur J Pharmacol 147:465-467

Heilig M, Widerlov E (1990): Neuropeptide Y: an overview of central distribution, functional aspects, and possible involvement in neuropsychiatric illnesses. Acta Psychiatr Scand 82:95-114

Holmes PV, Davis RC, Masini CV, Primeaux SD (1998): Effects of olfactory bulbectomy on neuropeptide gene expression in the rat olfactory/limbic system. Neuroscience 86:587-596

King PJ, Widdowson PS, Doods HN, Williams G (1999): Regulation of neuropeptide $Y$ release by neuropeptide $Y$ receptor ligands and calcium channel antagonists in hypothalamic slices. J Neurochem 73:641-646

Kronfol Z, House JD (1989): Lymphocyte mitogenesis, immunoglobulin and complement levels in depressed patients and normal controls. Acta Psychiatr Scand 80: 142-147

Krysiak R, Obuchowicz E, Herman ZS (1999): Interactions between the neuropeptide $\mathrm{Y}$ system and the hypothalamic-pituitary-adrenal axis. Eur J Endocrinol 140:130-136

Levine AS, Morley JE (1984): Neuropeptide Y: a potent inducer of consummatory behavior in rats. Peptides 5:1025-1029

Martire M, Pistritto G, Mores N, Agnati LF, Fuxe K (1993): Region-specific inhibition of potassium-evoked [3H]noradrenaline release from rat brain synaptosomes by neuropeptide Y-(13-36). Involvement of NPY receptors of the Y2 type. Eur J Pharmacol 230:231-234

Michel MC, Beck-Sickinger A, Cox H, Doods HN, Herzog H, Larhammar D, Quirion R, Westfall T (1998): XVI. International Union of Pharmacology recommendations for the nomenclature of neuropeptide $\mathrm{Y}$, peptide $\mathrm{YY}$, and pancreatic polypeptide receptors. Pharmacol Rev 50:143-150

Mikkelsen JD, Woldbye D, Kragh J, Larsen PJ, Bolwig TG (1994): Electroconvulsive shocks increase the expression of neuropeptide $\mathrm{Y}$ (NPY) mRNA in the piriform cortex and the dentate gyrus. Mol Brain Res 23:317-322

Nilsson C, Karlsson G, Blennow K, Heilig M, Ekman R (1996): Differences in the neuropeptide Y-like immunoreactivity of the plasma and platelets of human volunteers and depressed patients. Peptides 17:359-362

Overstreet DH (1993): The Flinders sensitive line rats: a genetic animal model of depression. Neurosci Biobehav Rev 17:51-68

Overstreet DH, Pucilowski O, Rezvani AH, Janowsky DS (1995): Administration of antidepressants, diazepam and psychomotor stimulants further confirms the utility of Flinders Sensitive Line rats as an animal model of depression. Psychopharmacology 121:27-37

Porsolt RD, Bertin A, Jalfre M (1977): Behavioral despair in mice: a primary screening test for antidepressants. Arch Int Pharmacodyn Ther 229:327-336 
Redrobe JP, Dumont Y, St-Pierre JA, Quirion R (1999): Multiple receptors for neuropeptide $\mathrm{Y}$ in the hippocampus: putative roles in seizures and cognition. Brain Res 848: 153-166

Redrobe JP, MacSweeney CP, Bourin M (1996): The role of 5-HT1A and 5-HT1B receptors in antidepressant drug actions in the mouse forced swimming test. Eur J Pharmacol 318:213-220

Rudolf K, Eberlein W, Engel W, Wieland HA, Willim KD, Entzeroth M, Wienen W, Beck-Sickinger AG, Doods HN (1994): The first highly potent and selective nonpeptide neuropeptide $\mathrm{Y} \mathrm{Y}_{1}$ receptor antagonist: BIBP3226. Eur J Pharmacol 271:R11-R13

Schlicker E, Gross G, Fink K, Glaser T, Gothert M (1991): Serotonin release in the rat brain cortex is inhibited by neuropeptide Y but not affected by ACTH1-24, angiotensin II, bradykinin and delta-sleep-inducing peptide. Naunyn Schmiedebergs Arch Pharmacol 343:117-122

Smialowski A, Lewinska-Gastol L, Smialowska M (1992): The behavioural effects of neuropeptide Y (NPY) injection into the rat brain frontal cortex. Neuropeptides 21 : 153-156

Small CJ, Morgan DG, Meeran K, Heath MM, Gunn I, Edwards CM, Gardiner J, Taylor GM, Hurley JD, Rossi M, Goldstone AP, O'Shea D, Smith DM, Ghatei MA, Bloom SR (1997): Peptide analogue studies of the hypothalamic neuropeptide $\mathrm{Y}$ receptor mediating pituitary adrenocorticotrophic hormone release. Proc Natl Acad Sci USA 94:11686-11691
Song C, Kelly JP, Leonard BE (1994): Alterations in immune and endocrine parameters following olfactory bulbectomy. Med Sci Res 22:593-595

Song C, Earley B, Leonard BE (1996): The effects of central administration of neuropeptide $\mathrm{Y}$ on behavior, neurotransmitter, and immune functions in the olfactory bulbectomized rat model of depression. Brain Behav Immun 10:1-16

Stanley BG, Leibowitz SF (1984): Neuropeptide Y: stimulation of feeding and drinking by injection into the paraventricular nucleus. Life Sci 35:2635-2642

Stogner KA, Holmes PV (2000): Neuropeptide-Y exerts antidepressant-like effects in the forced swim test in rats. Eur J Pharmacol 387:R9-R10

Vezzani A, Sperk G, Colmers WF (1999): Neuropeptide Y: emerging evidence for a functional role in seizure modulation. Trends Neurosci 22:25-30

Widdowson PS, Halaris AE (1991): Chronic desipramine treatment reduces regional neuropeptide $\mathrm{Y}$ binding to Y2-type receptors in rat brain. Brain Res 539:196-202

Wieland HA, Engel W, Eberlein W, Rudolf K, Doods HN (1998): Subtype selectivity of the novel nonpeptide neuropeptide Y Y1 receptor antagonist BIBO 3304 and its effect on feeding in rodents. Br J Pharmacol 125:549-555

Willner P (1997): The mesolimbic dopamine system as a target for rapid antidepressant action. Int Clin Psychopharmacol 12(Suppl 3):S7-14 